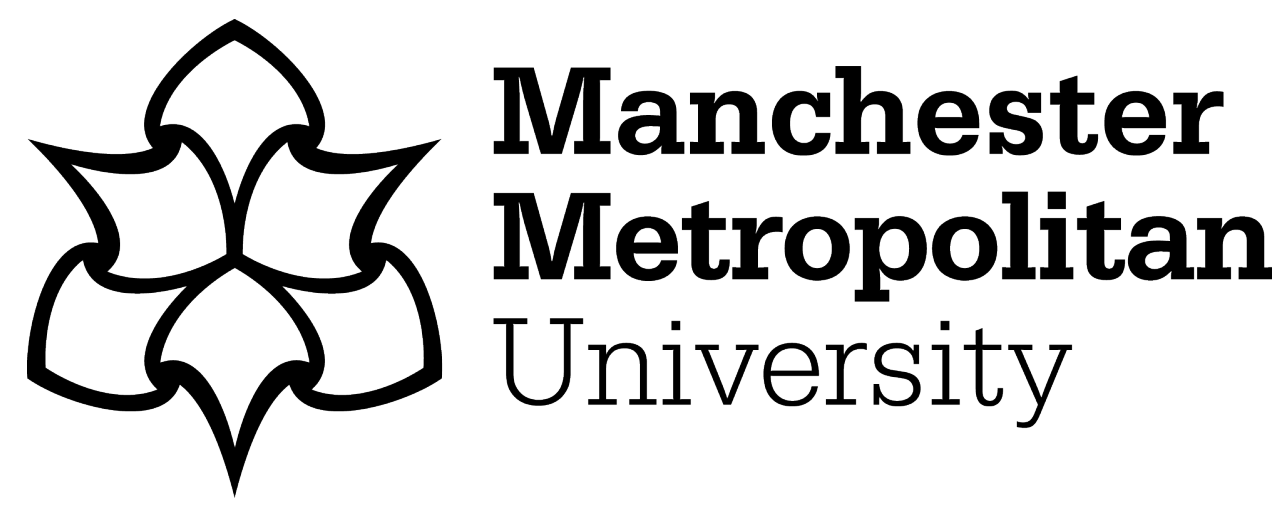

Bresnen, M, Hodgson, D, Bailey, S, Hassard, J and Hyde, P (2019) Hybrid managers, career narratives and identity work: a contextual analysis of UK healthcare organizations. Human Relations, 72 (8). pp. 1341-1368. ISSN 0018-7267

Downloaded from: https://e-space.mmu.ac.uk/621396/

Version: Accepted Version

Publisher: SAGE Publications

DOI: https://doi.org/10.1177/0018726718807280

Please cite the published version 


\title{
Hybrid managers, career narratives and identity work: A contextual analysis of UK healthcare organizations
}

\author{
Mike Bresnen \\ Manchester Metropolitan University and the University of Manchester \\ M.Bresnen@mmu.ac.uk \\ Damian Hodgson \\ Alliance Manchester Business School, University of Manchester \\ Damian.hodgson@manchester.ac.uk \\ Simon Bailey \\ Alliance Manchester Business School, University of Manchester \\ Simon.j.bailey@manchester.ac.uk \\ John Hassard \\ Alliance Manchester Business School, University of Manchester \\ John.hassard@manchester.ac.uk \\ Paula Hyde \\ University of Birmingham Business School and the University of Manchester \\ p.hyde@bham.ac.uk \\ Author Accepted Manuscript \\ Accepted 3 July 2018 by Human Relations. To be cited as:
}

Bresnen, M., Hodgson, D., Bailey, S., Hassard, J. and Hyde, P. (2018) Hybrid managers, career narratives and identity work: A contextual analysis of UK healthcare organizations. Human Relations. Copyright (C) 2018 (The Authors).

For full paper go to:

http

\section{Acknowledgements}

This research was funded by the National Institute for Health Research Service Delivery and Organization (NIHR SDO) programme (project number 09/1002/29). The views and opinions expressed therein are those of the authors and do not necessarily reflect those of the SDO programme, NIHR, NHS or the Department of Health. 


\title{
Hybrid managers, career narratives and identity work:
}

\section{A contextual analysis of UK healthcare organizations}

\begin{abstract}
While hybrid managers are increasingly important in contemporary organizations (especially in the public sector), we know little about why or how they become hybrid managers, or how this is shaped by the interplay of professional experience and organizational circumstances. In pursuit of a more variegated, contextualised and dynamic understanding of hybrid management, this paper focuses on how individuals transition into managerial hybrids, emphasizing the dynamic and emergent nature of hybrid management identity. Studying managers in English healthcare, we employ the concept of identity work as expressed through career narratives to examine the influence of career trajectories and organizational experiences on emerging hybrid manager identity. The study identifies three broad managerial career narratives - aspirational, ambivalent and agnostic - and relates them to experiences of doctor and nurse hybrid managers in three healthcare settings. An interpretive analysis of these narratives reveals a more variegated, situated and dynamic interpretation of hybrid managerial identities than previously considered and underscores the importance of personal and organizational experiences in shaping emergent hybrid professional/managerial identity.
\end{abstract}

\section{Keywords}

Hybrid managers; identity work; healthcare; career narratives; management 


\section{Introduction}

Expectations on professionals within public service organizations to act more 'managerially' have grown in recent years (Davies and Harrison, 2003). Ironically, this has coincided with increasingly intense pressures on management across sectors and national contexts (e.g. Hassard et al., 2009) and the widespread denigration of management as an occupation and set of practices (Brocklehurst et al., 2010). Nowhere is this more so than in the public sector, where successive waves of institutional reform and organizational change have led to extensive delayering and the intensification of managerial work in healthcare and other sectors (Hyde et al., 2016). Like all managers, healthcare managers have struggled to develop a distinct knowledge base and professional identity (cf. Thomas and Linstead, 2002). Management within healthcare remains highly differentiated and widely distributed (Buchanan et al., 2007) and this impedes collective management identity. Moreover, healthcare managers also face challenges associated with changing policy and discourses surrounding role expectations, as well as medical profession dominance (Currie, 1997; Davies and Harrison, 2003; Waring, 2007).

Such countervailing pressures have complex implications in areas reliant upon professionalmanagerial hybrids (Noordegraaf, 2015). 'Hybrid manager' is typically used to describe "individuals with a professional background who take on managerial roles, requiring them to move between different organizational groups" (Croft et al., 2014: 1). In healthcare, this normally refers to doctors, nurses and other allied health professionals (AHPs) moving into team leadership and/or switching into general management (Fitzgerald and Ferlie, 2000; Llewellyn, 2001). In the NHS, such hybrid managers easily outnumber what Buchanan (2013) characterizes as non-clinical, 'pure play' managers. This reflects a number of advantages they possess: being often more effective in reconciling professional needs with managerial 
requirements (Llewellyn, 2001; Currie and White, 2012; McGivern et al., 2015); spanning disciplinary and practice boundaries, building relationships and brokering knowledge (Kislov, 2014; Burgess et al., 2015); and enjoying greater legitimacy, credibility and, therefore, influence when managing fellow professionals (Kitchener, 2000; Dopson and Fitzgerald, 2005; Burgess and Currie, 2013).

Such advantages ensure managerial hybridity is pervasive in healthcare (Buchanan, 2013). However, such pervasiveness also draws attention to the challenges implicit in the elision of clinical and managerial identities (Spyridonidis et al., 2015; von Knorring et al., 2016). Hybrid managers face the challenge of drawing upon a range of discourses, narratives and rhetorical strategies to create a sense of self and stabilize their role (Czarniawska-Joerges, 1994; Watson, 2008). They represent a site of intensive identity work, since management identity is a diffuse, unstable and ambiguous phenomenon which draws on multiple discourses that may shift over time (Watson, 1994; Collinson, 2003; Sveningsson and Alvesson, 2003).

Despite extensive research on hybrid middle managers in healthcare, the question of how they view career development and professional status and identity is still relatively unexplored (von Knorring et al., 2016). Our knowledge tends to derive from focusing on either doctor-managers (e.g. Llewellyn, 2001; Noordegraaf, 2015) or nurse-managers (e.g. Bolton, 2005; Currie, 2006; Currie et al., 2010). We also know little about how different hybrids emerge and how this is shaped by experiences across healthcare settings. Here, we seek to go beyond current understanding by building on distinctions made between types of hybrid manager (McGivern et al., 2015; Spyridonidis et al., 2015), given the various routes and motivations for accepting a hybrid position. This approach involves recognizing that hybrid managers have different career trajectories and perform roles in diverse organizational settings (cf. Dopson et al., 2008). 
As such, it is important to gain a more situated and dynamic understanding of hybrid managers' aspirations, their career options, and how they seek to reconcile clinical and managerial identities.

We therefore investigate hybrid managers' orientations towards their activities and roles, career development and professional status, and explore how these orientations have been, and are being, shaped by managers' occupational backgrounds and organizational experiences. We focus upon career narratives to gain insight into hybrid managers' identification with particular professional/managerial groups (Knights and McCabe, 2003). Studying managers in the English healthcare system, the research employs the concept of identity work to explore how hybrid managers make sense of their careers and construct their own emerging sense of occupational identity (Alvesson et al., 2008; Alvesson, 2010; Brown, 2015; Watson, 2008). This allows us to consider how clinical and managerial identities have co-evolved - or coalesced or fractured - in the light of professional development and organizational experiences. We explain what this means for a more nuanced interpretation of 'hybridity' in healthcare management when account is taken of the variety of managerial career trajectories and range of organizational circumstances encountered.

\section{Hybrid managers in healthcare}

Given their importance to contemporary healthcare organizations (Buchanan, 2013) and the integration challenges such organizations face, it is unsurprising hybrid managers have provoked interest. They have been considered important in bridging the clinical-managerial divide (Llewellyn, 2001) and brokering knowledge across multi-disciplinary teams (Currie and White, 2012; Burgess and Currie, 2013; Ferlie et al., 2013). As such, they act as boundary 
spanners who connect clinical and managerial communities of practice (Fitzgerald \& Dufour, 1997; Fitzgerald \& Ferlie, 2000; Kislov, 2014). Hybrid managers also play a potentially important role in translating management initiatives into practice (Currie, 2006; Dopson and Fitzgerald, 2006; Burgess et al., 2015).

Simultaneously, hybrid managers face many personal and professional challenges (Currie, 2006; Burgess and Currie, 2013; Croft et al., 2014, 2015). Apart from their comparative lack of management training (Iedema et al., 2004) and the practical difficulties of combining clinical and managerial workloads (Currie et al., 2010; Kippist and Fitzgerald, 2009), taking on management responsibilities implies an attenuation of professional status and identity (Dopson 1995; Dopson \& Fitzgerald 2005; Fitzgerald \& Ferlie, 2000; Croft et al., 2014; Noordegraaf, 2015). Clinicians can find it difficult to reconcile professional norms/values with management expectations and organizational goals (Kippist and Fitzgerald, 2009). The choice for them may be between retaining a clinical identity (by avoiding management responsibilities), or being co-opted into management to develop their career (Dellve and Wikström, 2009; Burgess and Currie, 2013).

What this hybridity means for organisations, the power and influence of managers and those occupying hybrid roles is contested. On the one hand, it has been suggested that the shift towards greater managerialism means professionals in healthcare and other public services have been assimilated into management through hybrid roles (Fitzgerald and Ferlie, 2000; Currie and Croft, 2015; Noordegraaf, 2015). Consequently, hybridity appears to represent an encroachment of managerial control and a weakening of professional power (Davies and Harrison, 2003). On the other hand, research suggests limits to the spread of managerialism, as powerful professional groups (such as clinicians) can harness management systems and 
knowledge to sustain and even increase their professional influence and elite status (Dopson, 1995; Thorne 1997; Waring, 2007).

At one level, this difference could signify that, while clinicians may have always experienced hybridity, the wave of reforms associated with managerialism and marketization in healthcare has changed both the scale and character of hybridization - creating a more complex landscape within which hybridity plays out (Fitzgerald and Ferlie 2000). At another level, however, the apparent contradiction can also be explained by an error of generalisation - in treating all hybrid management roles as equivalent. As Currie and Croft (2015) suggest, differences in professional status and power between doctors and nurse managers, although often glossed over in research, have important potential effects on their enactment of hybrid roles. Doctors, especially those in powerful organizational positions, have been adept at reconciling and channelling competing bases of identity and influence and responding flexibly and creatively to different contexts as (senior) hybrid managers (McDermott et al., 2013). Llewellyn (2001) describes not only how they occupy the 'two-way space' through which clinical and managerial needs are mediated and reconciled, but also how they can carve out new identities as medicalmanagers - whose enhanced influence is limited only by their lack of financial expertise. Similarly, Iedema et al. (2004) show how doctor-managers can develop complex dialogic strategies that effectively weave seemingly incommensurate discourses (clinical, managerial) into a seamless narrative.

Nurse hybrid managers depend too upon their clinical background to help bridge the clinicalmanagerial divide and engage in strategically important work (Currie, 2006; Burgess and Currie, 2013; Burgess et al., 2015). However, research suggests their lower occupational status means they tend to rely upon more informal bases of influence (Currie and White, 2012). They 
may even resort to managerial discourse to help bolster their status and influence (Brooks, 1999; McMurray, 2010). At the same time, nurse hybrid managers can appear less willing than other managers to embrace commercial or entrepreneurial aspects of their role (Bolton, 2005). They can also struggle to contain internal conflicts associated with reconciling clinical and managerial interests (Croft et al., 2014).

Other research into hybrids identifies greater variation in the types that exist - beyond nurses and doctors, or other fixed roles - and attempts to capture more of the heterogeneity of hybridity in practice. McGivern et al. (2015), in particular, highlight attitudinal differences between 'incidental hybrids' - whose primary interest is clinical work - and 'willing hybrids', who are more likely to embrace their managerial role and identity. While this differentiation provides greater appreciation of the diversity of managerial hybrids, there is limited value, however, in simply subdividing the hybrid manager role into binary categories. What is needed is research which engages fully with the shifting nature of hybrid identity and which looks longitudinally at the process by which identity emerges and is influenced by the interplay of professional/occupational background and organizational experiences.

We argue there is a need to attend to the transition to hybridity and how this is associated with the reconciliation of professional and managerial identities (Croft et al., 2014, 2015; Currie and Croft, 2015). It is recognized that "through lengthy educational and socialization processes, professionals develop intense connections to their work and come to define themselves with respect to the goals, values, norms, and interaction patterns associated with their work" (Reay, 2017: 1045). Yet only rarely are attempts made to understand how different occupational types emerge in the transition from clinical professional to hybrid healthcare manager. Spyridonidis et al. (2015) provide one exception, in differentiating between physicians who are 'innovators', 
'sceptics' or part of the 'late majority' in taking up hybrid clinical-managerial roles. Drawing upon the concept of identity salience (Ashforth, 2001), they examine physicians' reactions to greater management responsibilities as a dynamic process, noting how the transition involves shifts between nested identities and/or the acceptance of a new hybrid identity. Similarly, Ferlie et al. (2013) use the concept of identity work to show how senior clinical hybrids enact their leadership roles, framing and constructing reality over time in ways that help enrol professional colleagues in knowledge mobilization initiatives (specifically, evidence based management).

Other research points to a long period of transition, such that clinical identity retains a stronger influence upon the self-image and actions of hybrid managers than any recently-acquired managerial identity - with even 'willing hybrids' (McGivern et al., 2015), or those for whom managerial identity has some salience, tending to default to a clinical perspective on management issues (Iedema et al., 2004). According to von Knorring et al. (2016: 430), even though doctor hybrid managers draw upon both clinical and managerial discourses, the former tend to dominate and can thus render managerial identity effectively 'invisible'. While the question remains as to whether or not this ultimately reinforces the stratification of power in healthcare - potentially favouring medical staff over managers (cf. Currie et al., 2009) - at the level of management practice, it does suggest there are varying trajectories along which hybridity emerges and develops and that these are strongly influenced by the interplay of personal career aspirations and organizational circumstances (cf. Noordegraaf, 2015).

The above discussion suggests the need to be mindful of how hybrid managers' positioning within hierarchies, combined with their professional status as doctor or nurse (Currie and Croft, 2015), shapes career trajectories and emergent professional/managerial identity. We currently lack knowledge about how the construction of hybrid managers' identities is influenced by the 
interplay of personal experience and organizational circumstances, and how this is reflected in the development of management careers (cf. Watson, 2008). Research which explains the various ways in which hybridity develops is invaluable (Noordegraaf, 2015; Spyridonidis et al., 2015). What is currently lacking is greater in-depth examination of the identity transitions of different types of hybrid manager. To address this shortfall, we draw on the concept of 'identity work' (Sveningsson and Alvesson, 2003) as a means to capture the heterogeneity, complexity and fluidity of occupational identity while elucidating the temporal dimension of identity formation, on one hand, and contextual influences on the other.

\section{Hybridity, identity work and career narratives}

Recent work on managerial identity has moved from understanding it as a fixed, stable and coherent concept to emphasizing its situated and changing character (Watson, 2008; Collinson, 2003; Sveningsson and Alvesson, 2003; Brown, 2015). Managers are a fragmented occupational group whose work takes place across diverse settings. They also lack any common set of professional norms, standards and practices or system of professional accreditation (Watson, 1994). To give meaning to their work and role, managers tend to draw instead upon a variety of alternative and sometimes competing bases of identification (professional, organizational, personal). This represents a move away from exploring the nature of fixed identities and towards emphasizing the processes and practices of identification (Knights and McCabe, 2003). Managers mobilize a potentially wide range of discourses, narratives and rhetorical strategies to help create a sense of self and stabilize their role (e.g. Czarniawska-Joerges, 1994). At the same time, the likelihood that such discursive resources have ambiguous or conflicting meanings ensures that managers struggle to establish a clear sense of identity (Sveningsson and Alvesson, 2003). Management identity is therefore best 
understood as a provisional and negotiated accomplishment (Collinson, 2003; Alvesson et al., 2008), involving intensive identity work (Sveningsson and Alvesson, 2003; Alvesson, 2010: 89).

For hybrid managers, who face the need to reconcile different agendas in their day-to-day work, this struggle is arguably even greater and perhaps more likely to result in intense identity work to create a coherent self-image. Individuals who are caught between, or expected to inhabit, two worlds simultaneously, can be described as being in a liminal position (Beech, 2011). Such liminality may be temporary, as people move from one role to another - through promotion or change of career direction, for example (Tansley and Tietze, 2013). However, for managers in hybrid roles, whose remit requires a more continuous effort to combine managerial and other professional interests, the tension is more permanent (Paton and Hodgson, 2016; Barber et al, 2017). It requires constant and intense identity work, and many may struggle to reconcile competing demands, both in their everyday conduct and in pursuing a coherent sense of self (Croft et al., 2014). Managers may respond in a variety of ways - by privileging one aspect of identity over another, or attempting to reconcile different assumptions and meanings. Given these complexities, it becomes even more important to recognize the diffuse, fluid and accomplished nature of hybrid managerial identity.

Recent explorations of identity work have therefore stressed not just the influence of organizational and extra-organizational sources of meaning, but also how these relate to managers' own self-identities and how balancing the two can impact upon identity construction (Ibarra, 1999; Kreiner et al., 2006). According to Watson (1994, 2008), managers are not only engaged in constructing their own identity, they also face the challenge of reconciling their self-concept with extraneous sources of meaning that circulate through professional and 
organizational discourses (Kreiner et al., 2006). Watson (2008: 128) characterizes this as building a bridge between managers' self-identity and external, discursive social-identities. Consequently, it becomes important to understand how individuals respond to (changing) organizational circumstances and institutional pressures (Ibarra, 1999; Kreiner et al., 2006).

Context, therefore, and its interpretation, is again vitally important in understanding the formation of identity (Ferlie et al., 2013; McDermott et al., 2013). In institutionalized and professionalized environments, such as healthcare, one might expect organizational demands and professional requirements to strongly influence managerial identification. McDermott et al. (2013: S94), for example, point to context as "dynamic situational opportunities and constraints that shape behaviour or impact events" and explore the affordances of different contexts and the skills of individual agents in shaping a variety of possible roles. In a landscape as complex and changing as healthcare, it is important therefore to consider what freedom of action managers may have to accept, manipulate or even resist organizational and other institutional pressures to conform to particular expectations of their role or identity (Watson, 2008; Brown, 2015: 26).

Tapping into managers' identity work, as expressed through the narrative self-identities they present (Sveningsson and Alvesson, 2003), is thus an important way of appreciating how hybrid managers understand themselves (Czarniawska-Joerges, 1994; Watson, 2009), and how this sense-making is shaped by, and in turn shapes, their circumstances (cf. Weick, 1995). Identity work is often revealed in career narratives through which managers seek to make sense of their career progression (Ibarra and Barbulescu, 2010). Such narratives help capture the socialization processes associated with starting careers and/or joining organizations (Ibarra, 1999; Ashforth, 2001). They also help capture enduring efforts to make sense of managerial 
roles and organizational expectations (Weick, 1995). Career narratives can, of course, overlook what has been a more fragmented set of career changes (e.g. Learmonth and Humphreys, 2012). Nevertheless, they can yield important insights into how managers relate to particular constructions of identity and the actions they take to build upon synergies or resolve contradictions. Furthermore, their inherently retrospective or longitudinal nature helps provide insight into how changing contextual conditions might consolidate, or fracture, hybrid managers' sense of identity throughout the course of their careers.

In what follows, we explore the career trajectories of different kinds of hybrid manager in healthcare and examine how these have been shaped by the conditions faced. The career narratives presented reveal a much more nuanced picture of career development and managerial identity than in the dualisms commonly used to contrast clinician and manager, or willing and incidental hybrid. Through examining how orientations to management relate to career development, and how these are infused with processes of sense-making (cf. Watson, 2008), the paper contributes to understanding hybridity in healthcare management by pursuing two inter-related questions. First, what is the range of orientations to management found amongst hybrid managers as reflected in their career development narratives? Second, how has this been shaped by managers' occupational/professional backgrounds and organizational experiences?

\section{Research methods}

To explore these questions, data is drawn from an NIHR (National Institute of Health Research, UK) funded study into how managers learned, applied and shared knowledge in a variety of healthcare contexts. Attention was directed to understanding the career pathways taken by managers and how their professional backgrounds and experiences shaped orientations to 
management. The novelty of the approach lay in the attempt to make sense of identities and career development across a diverse mix of managerial role-holders and healthcare organizations.

Three hospital trusts, based in the same English region, participated in the study. They were selected to represent different types of activity and comprised: a general hospital (Acute); a mental health and community services provider (Care); and a hospital offering specialist, tertiary care (Specialist). The contextual features which informed our choice included their geographical reach, the number of service operation locations, the diversity of services and the number of organizations purchasing their services. The Acute trust offered a wide range of services centralized in one location, covered a limited (local) geographical area and dealt with one commissioner. The Care trust delivered a diverse range of mental health and community services with operations distributed in many locations over a large (regional) geographical area, contracting with multiple health and social care commissioners. The Specialist trust offered a narrow range of highly specialized services mainly from one central location to patients spread across a very wide (regional and national) geographical area, and dealt with multiple commissioners.

Within each trust/hospital, managers were selected on the basis of a framework that differentiated three broad clusters - clinical, general and functional (see Figure 1). Within each cluster, managers were sampled purposively across a range of operational and functional areas. They were selected for interview if they met a definition of 'middle manager' that placed them at least two levels up or two levels down the formal managerial hierarchy (McConville, 2006: 639). 
Semi-structured interviews, conducted by at least two members of the research team constituted the core methods of data collection. In total, 68 respondents were interviewed (some more than once) and interviews lasted between 1-2 hours (see Table 1 for a breakdown by trust and management cohort).

\section{TABLE 1 ABOUT HERE}

Interviews were conducted between 2011 and 2013, when some of the largest changes ever made to the NHS were being enacted. This shaped the kind of data collected, with questions concerning change taking prominence and evoking extensive responses. Rather than being a discrete category at the end of the interview schedule, change became the context within which all other management activities tended to be portrayed. This drove an analytical focus on how managers' interpretations were shaped by operational, organizational and other pressures they faced at the time of research.

All interviews were digitally recorded and transcribed, and supplemented with background information on the interview and interviewee. The primary data set consisted of 139 recorded hours' interviews $(924,000$ words). Data were coded and analysed using NVivo software. Interview schedules and subsequent coding were organized around five broad themes: career, knowledge, relationships, organization, and change. These themes informed the design of the schedule and presented an initial coding framework. More detailed coding was then driven inductively, through collective coding of a sample of interviews and informed by regular meetings of the research team to discuss the emerging analysis, explore contradictions and disagreements and develop consensus. Throughout analysis, the coding framework remained open to the inclusion of additional categories or deletion/combination of nodes. Following 
coding, thematic analysis and interpretation of data proceeded with individual team members responsible for developing particular axial themes. This process was also iterative, with team meetings, presentations and comments on drafts used to ensure accuracy and consistency of interpretation.

\section{Managers' career narratives and perspectives on management}

Table 2 summarizes the clinical/health backgrounds and qualifications of managers across the sample. All clinical managers and most general managers had clinical experience - with the exception of some general managers at the Specialist and Acute trusts. Most managers in the sample, including some 'pure play' (cf. Buchanan, 2013) and functional managers, had at least one healthcare or healthcare management qualification (at BSc, PG Diploma or MSc level). Amongst clinical and general managers, therefore, hybrid managers were the dominant group, outnumbering 'pure play' managers by a 4:1 ratio (i.e. $36: 9$ ). The following discussion refers only to these hybrid managers and not their 'pure play' or functional counterparts.

\section{TABLE 2 ABOUT HERE}

Hybrid managers were particularly prevalent in the Care trust, where most general managers came from a nursing background. Managers with a nursing background were also by far the largest number of hybrid managers (21, compared with 9 clinicians and 6 occupational therapists and social workers). Most nurse hybrids had developed their careers through the nursing grades, before moving into management via senior nursing positions, including ward sister and matron. Progression was often associated with gaining experience in a variety of clinical domains (particularly in Acute) and/or in different service operations (particularly in 
Care). At the Specialist trust, nurses' involvement in research and teaching were additional routes into management.

Across the sample, motivations for moving into management positions were diverse, as were the opportunities available to such 'proto-managers' in developing their careers. However, through coding, it was possible to discern three types of hybrid manager - aspirational, ambivalent, agnostic - sharing broadly similar career narratives. Table 3 uses quotes from respondents in each of these categories to illustrate each type of hybridity and orientation to management.

\section{TABLE 3 ABOUT HERE}

Career narratives for these exemplars are elaborated through tabulated accounts (Tables 4-6) to explore orientations towards, and transitions into, management, as well as circumstances shaping the development of their careers. Where appropriate, these accounts are augmented with responses from other hybrid managers across the sample.

\section{Aspirational hybrid managers}

Although all hybrid managers interviewed emphasized the importance of clinical background and identity, there was little evidence amongst doctors of choosing management as a positive career choice. Amongst nurse hybrid managers, the picture was different and, as the accounts of Melissa, Hasin and Becky in Table 4 (as well as others) suggest, there were some for whom moving into management had always been a guiding ambition.

\section{TABLE 4 ABOUT HERE}


About half the nurse hybrid managers interviewed either started with aspirations of moving into management or decided it was a career path that would help them have a greater impact on patient care. For these aspirational nurse hybrid managers (including former matrons), only a move into management could provide them with the opportunity to exert greater influence. The counterpoint, however, was the absence of an alternative nursing career path; one providing opportunities for a management career while still retaining clinical identity. As Annette put it:

At the time I was working, there was no career development in nursing, so you were either ward manager or went into service management. (Annette, General Manager, Specialist)

Such comments on the lack of a dual career path were typical and mirrored those of others interviewed, such as Gloria (Acute), who talked of the 'glass ceiling' it created for nurses.

While there was commonality amongst this group, in their intended (if somewhat forced) transitions into management and their internalization of managerial identity, there were nuances that signified important contextual differences between the trusts. Overall, management was seen as a more 'normal' career move for aspirational nurse hybrid managers at both the Care and the Acute trust. As Melissa's narrative (Table 4) suggests, the greater diversity of clinical specialisms and services in the Acute trust put a premium on career development through managing inter-disciplinary teams and/or integrating clinical services. In the Care trust, Hasin's narrative also reflects such diversity and the need to integrate operations and build/integrate new outreach community services. However, at Care, these challenges were often more intra-service than inter-disciplinary; and reflected how managerial development through a narrower clinical base (psychology and physiotherapy) and more specific patient 
group also significantly shaped the demands on, and opportunities available for, aspiring managers. As another aspirational hybrid manager noted:

One of the things that drives me ... [is] to feel comfortable with service users and that I know them. It was a client group I felt I had something to offer ... which enabled me to do some of the other [management] work I needed to do a bit outside my comfort zone. (Beth, Service Manager, Care)

In the Specialist trust, Becky's account (and others' - see Beryl, for instance) put a strong emphasis on their specialism, but also on the wider pathways for development associated with opportunities that their specialized clinical work opened up - through research, private work, teaching and wider (institutional) secondments.

All these nurse hybrid managers shared a belief that moving into management was both a natural progression and one which allowed them to combine clinical interests with opportunities to exert greater executive influence. For some, that ambition had been influential throughout their career. As such, they could be described as 'willing hybrids' (McGivern et al., 2015). On the other hand, the absence of any genuine alternative career path through nursing meant the only choice was to move into service management. This does not mean that such managers were any less aspirational; for there was clear evidence of a desire to 'make a difference'. For example:

I felt this job, because it was a clinical service manager post, would be my first proper full time operational management role. But also because of the clinical focus it would mean I would also have the ability and power to drive the things I felt were important - in terms of quality of care. That's why I came into this role. (Beth, Service Manager, Care) 
Instead there was evidence this group found it relatively easy to reconcile acquired managerial identity with clinical experience through a collective focus on the values of improving patient care. However, there were also situational differences in the ways in which they were then able to progress their careers.

\section{Ambivalent hybrid managers: nurses}

While many aspirational nurse managers displayed strong intent in the pursuit of a managerial career, there were others for whom progression into management was unintentional or accidental. More than half of the nurse managers felt this, as did virtually all clinical managers. Harriet's account was similar to many other nurse hybrid managers' accounts (see Table 5).

\section{TABLE 5 ABOUT HERE}

Rather than describing their careers as a chosen pathway with a clear end point, they instead considered themselves to have been, as Belinda (Acute) put it, in the "right place at the right time' and thus able to develop their careers partly through a series of incremental steps or opportunistic moves.

While the ambition to become managers may not have been strong within this subgroup, their identification with management certainly could be. Many were comfortable with their progression into management, even where it was unexpected, and this led them to identify with management. However, for other, initially more reluctant nurse managers, identification took a more circuitous route, involving considerable calculation and/or rationalisation. The calculations involved were expressed vividly in Belinda's account:

When I took my management role ... I used to go home and think: God what have I done today. What am I being paid for, this is just ridiculous ... [It was] about six months 
until I really got into it. This is just silly, I should be with patients ... I still did have a bit of clinical work initially, but in the end you just couldn't do either effectively. (Belinda, Therapies Manager, Acute)

While the rationalization involved comes across strongly in Nina's account:

[I was] asked to consider trying [the job] for six months ... So I thought about it because I felt very comfortable with the clinical leadership and managing what I'd done and I felt I'd built up a really good service I was very proud of. My heart was very much in that and I'd never considered going into a purely management role, it had just never entered my head. So I agreed I would try it for a period of six months, which went to a bit longer. I realized that, hey I'm not bad at this; I quite like it as well. (Nina, Divisional Lead Nurse, Specialist)

Interestingly, such calculative/rationalized engagement with management was more strongly expressed by nurse hybrid managers at the Specialist and Acute trusts. Nurses at Specialist tended to be more embedded in, and committed to, specialist clinical domains (e.g. chemotherapy, as in Hannah's case). Nurses at Acute had more attenuated links with particular clinical domains - having diversified their role into managing multi-disciplinary teams - but still considered their baseline clinical identity to be important. At Care, there was less disparity felt between managerial role and clinical identity. As Harriet's account suggests, it was seen as more normal there for nurses to progress seamlessly into general management positions.

Often such moves by nurses into management were prompted by organizational changes resulting from reorganizations brought about by wider healthcare reforms and/or growing financial pressures. There were important differences in the nature of changes occurring at each trust and in the consequent threats and opportunities this created for managers in developing their careers. Financial pressures were most strongly felt at the Acute trust (a traditional district general hospital). At Care, the integration of a growing, yet highly differentiated, organization 
was a pressing strategic concern; there were also development opportunities for managers associated with the trust's expansion into community services, that needed developing or bringing in-house. The prestigious work undertaken at the Specialist trust also protected it somewhat from financial pressures and associated cuts, and provided opportunities for growth through new business development and specialist services provision (e.g. clinical trials).

At the same time, however, while job cuts, management delayering, and functional reorganization (especially at Acute and, to some extent, Care) created obvious threats and disruptions to managerial careers, they also presented opportunities for nurse managers to develop careers through alternative pathways. This is clearly expressed in Roxanne's account of her transition from community-based nursing/midwifery to being an exponent of 'modernization'. Initially reluctant to embrace management, Roxanne's account shows how striking a new managerial identity can be aligned with management initiatives linked to performance improvement. In her case, an initial reluctance to become a manager was soon transformed into a seemingly deep internalization of, and identification with, management values, goals and methods (cf. Waring, 2007). Most noticeably, it was at the Acute trust, faced with the greatest financial pressures, where such (internal) performance improvement agendas were most prominent and widespread; although conditions at Care also created significant (external) opportunities for managers to develop new services or integrate established ones.

\section{Ambivalent hybrid managers: doctors}

The career development of hybrid managers from a medical/scientific background followed more of a standard pathway through the clinical grades (from medical degree onwards) and there was less evidence of such 'normalized' transitions into management. There were however exceptions - such as Bethany at the Acute trust, who described how she 'morphed into a 
business manager' from a clinical role. Nevertheless, for most doctors (like some nurses at the Specialist trust), stepping into management was a more cautious affair, as accounts in Table 6 explain.

\section{TABLE 6 ABOUT HERE}

A key concern for many doctors was the challenge in reconciling management responsibilities with clinical caseloads and expertise. As Brian (Associate Medical Director, Acute) put it:

The trouble is you have to sacrifice quite a lot of clinical time and maintaining skills requires that you do it regularly. If you look at the job I've now taken on ... probably a third of my working week is management time.

This could create serious doubts about what moving into management meant for one's identity as a clinician. Indeed, in Table 6 , there is clear evidence of such concerns - particularly in the accounts of doctors at Specialist and Acute -for reasons again linked to their clinical specialisation.

At one level, these accounts suggest clinical managers could be considered 'incidental hybrids' (McGivern et al., 2015), encouraged or cajoled into a managerial role but still strongly clinically oriented. However, it was evident too that, as with some nurses (at Specialist and Acute) there was more ambivalence than this might suggest about how to reconcile clinical and managerial responsibilities, knowledge bases and professional identity. There was also more than a hint of rationalization in how they made sense of their move into management. Brian went further than most in describing how his transition from reluctant to willing manager was accompanied by active embracing of his managerial remit and identity: 
It wasn't a planned career path ... One of the senior consultants said: "you know, we're struggling to find a clinical director and I think you'd be the best person for the job. You're going to have to do it." And I went home and said to the wife: "oh my God!" And, in all honesty, I did it because, I thought, well, somebody has got to do it and, if I say no, how can I expect somebody else to do it?

The first couple of years were very hard ... There was a lot of lost sleep ... But, at the end of 18 months, I found myself coping okay ... At the end of five years, I found I was doing it quite calmly ... [Now] I quite like to describe myself as a medical manager. Because I like to not pretend I'm one of the clinicians who only does management resentfully ... I like to say: "no, you know what? I'm one of the baddies. I'm on the other side".

In reconciling clinical and managerial orientations/identities, it was clear that contextual conditions played an important part. This comes across explicitly in Ramesh's account (Table 6), in which he explains how internal task and organisational conditions (speciality, location of work, cultural values) played an important part in enabling his transition into management. Similar contextual factors come into play in other accounts - notably, Robert's reference to income generation possibilities as a significant enabling factor and, in contrast, the inhibiting effect of expectations on Brenden to take a more strategic overview.

\section{Agnostic hybrid managers}

Among clinicians, and also some nurse hybrids, there were those strongly disinclined to accept the mantle of manager. This tended to be the result of either perceived incommensurability between clinical identity and managerial expectations (particularly amongst doctors) or due to negative experiences of management that created a desire to return to core clinical competences (particularly amongst nurses). Associate Medical Director Brian eloquently outlined the 'case against' from a doctor's point of view: 
What are the incentives for being a manager? It's about changing the environment you work in, improving the hospital, making it work more efficiently ... [But you're] carrying on your clinical practice while taking on a huge amount of excess baggage ... It's not financially rewarding, particularly. The only reward is seeing the department evolve into the kind of department you want it to be. Well, you could say that's a great incentive and, indeed, that's why I do it. But I'm not sure that's a massive draw for a lot of people.

Nevertheless, there were cases of both doctors and nurses who were at least willing to have taken on the role. As Oliver, Chief Pharmacist at Acute, recalled:

I became the manager of medicine and that was an incredibly operational role. I did that for two years and that was very much the classical bed pressures, getting people out of A\&E, [etc]. But I did other things as well, like introduce proper governance arrangements in medicine ... and we turned medicine round. It was a good experience, and it certainly gives you an insight into organizations and the challenges.

For some who had transitioned into management (e.g. from team leader or senior clinical roles), the unexpected and accidental nature of the move (including 'acting up' during reorganizations, or having to combine managerial work with significant continued clinical caseloads) had created stress, which could drive them back into clinical work. Justine was one, as her account in Table 3 made clear - although she was also open to managerial challenges associated with developing or integrating services:

A brand new service was being set up ... and that was always attractive to me, because I knew I could ... set things up and it would be successful ... But I was missing client contact [and] the cut and thrust of daily services ... So I decided to go for the post here ... I love it here, I love the work. 
For others, it was the intrinsic pressures of managerial work, or the context in which managers were expected to act, that left them amenable to, but psychologically rather agnostic towards, management. As Modern Matron at Care, Thea, suggested:

I loved managing staff that were easy to manage, but managing staff that were difficult to manage was quite a challenge and I was just burnt out ... Working with clients is one thing. Managing and working staff that are quite difficult is another and emotionally can drain you.

Other nurse hybrids that had encountered stressful experiences, or were simply reluctant to become senior managers, tended to displace their career development efforts into more diversified nursing portfolios or junior management roles.

While there were many personal and situational factors influencing the orientations of this diverse group, the narratives also reveal points reinforcing earlier-noted contextual influences on managerial career progression. Notably, the importance of clinical specialism, crossdisciplinary orientation and performance improvement initiatives at Acute (Oliver); the significance of the user group and building or integrating services at Care (Justine); and the variety of avenues available for developing managerial careers at Specialist (Beryl, Table 3). As such, they lend further weight to the influence of contextual factors in shaping both management careers and identities.

\section{Discussion}

There are two, inter-related questions this research addresses. First, how adequately do existing conceptions of hybridity capture the orientations to management and career transitions amongst 
healthcare managers? In other words, how useful are static, dualistic frameworks for understanding multifarious, emergent and dynamic hybrid management identities (cf. McGivern et al., 2015; Spyridonidis et al., 2015)? Second, how have these identities been shaped by managers' occupational/professional backgrounds and organizational experiences (cf. Dopson et al., 2008; Noordegraaf, 2015)? While existing work examines situated managerial action (e.g. Currie and White, 2012), it often presumes healthcare managers face similar or identical organizational/institutional settings and thus underestimates the impact of diverse circumstances/experiences on hybrid managers' emergent management identity.

Taking the first research question, what the interview data highlights is greater variability in experience, career transitions, and orientations to management than suggested in work framing hybridity as a dichotomy between types of manager. While it is important to avoid the other extreme - that each manager's professional experience is unique - this analysis has identified three main identity narratives - aspirational, ambivalent and agnostic - that capture much of this variation. In addition, further variance is highlighted within each narrative, reflecting differences between doctors and nurses in their orientations to management as a career and source of professional identity (see Tables 3-6).

What these narratives suggest is a more complex, layered and dynamic set of orientations to hybridity than are presented in current research offerings. As useful as existing dichotomies are for understanding general tendencies, they do not capture the subtle nuances associated with quite different career development trajectories. These differences reflect not only whether moves into management are aspirational (a desired goal), ambivalent (involving mixed feelings) or agnostic (characterized by doubt), but also whether the transition into management is more intended or accidental and more linear or circuitous (and with what effects). As such, 
they present a more nuanced, ethnographically-inspired picture of the micro-dynamics of transition across multiple, internal occupational boundaries that is often called for in research on contemporary careers (Rodrigues and Guest, 2010; Inkson et al., 2012).

In addition, the analysis has captured what this means for hybrid managers' identification with management and how this varies between doctors and nurses. In doing so, it has surfaced some differences in perspective of those with varying hierarchical roles and occupational longevity. Importantly, the data signify differences in the levels of internalization of management identity: from full identification and commitment in the case of many aspirational nurse hybrids; to more incremental and 'normalized' transitions by other, more ambivalent nurse hybrids; to more calculative involvement and/or rationalization in the case of most (ambivalent) doctors and some equally strongly clinically-oriented (frequently senior) nurses; to reluctant acceptance and even resistance by some (agnostic) doctors and nurses.

Two points are worth emphasizing. First, while the orientations of doctor-managers and other hybrids (notably nurse managers) suggest broad differences, there are also some similarities when it comes to understanding managerial orientations. Clinicians may be broadly more reluctant (or 'incidental') and nurse managers more committed (or 'willing') hybrid managers. However, this is by no means clear-cut. Both groups are as likely to fall into the category of ambivalent managers who are, in different ways, assimilated into management. It is this category of hybrid manager perhaps in which the most interesting sense-making processes of acceptance, calculation and rationalization occur, and where internal struggles over managerial and clinical identity appear to play out most fully (cf. Croft et al., 2014, 2015). Managers located on other parts of the spectrum (aspirational or agnostic) were clearly aware of the 
tensions but much less likely to suffer the discomfort of trying to reconcile their clinical and managerial identities. Instead, they either embraced their managerial identity or rejected it.

Second, there is an inherent fluidity in hybrid managerial identity formation that is difficult to ascertain from static categorizations of hybrid type. Instead, account needs to be taken of how orientations to management evolve over time and in relation to changing circumstances (Noordegraaf, 2015). This is most clearly shown in the career narratives of those doctor and nurse hybrids whose initial orientations to management were more reluctant and critical, but who came to embrace their role and influence as managers (notably Brian, but also Belinda, Roxanne, Nina and to some extent, Ramesh). Having reluctantly cloaked themselves in a managerial role, such clinicians were not only able to rationalize their move into management, but were also able to reconcile, through practical engagement, what they originally considered to be quite distinct logics, knowledge bases and professional identities. This is also apparent in the tendency for nurse hybrids to legitimize their engagement with management through adopting discursive strategies that draw upon managerial agendas of service improvement, modernization and the like (e.g. Roxanne). In both cases, there was a sublimation of what management represented into activities that could be seamlessly linked to improvements in patient care (cf. McDermott et al., 2013). The subsequent creation of an over-arching narrative thus helped to reconcile clinical and managerial forms of identity (cf. Currie and Croft, 2015). Interestingly, it was mainly those at the Acute trust that these felt tensions were commonly rationalized in this way. For those whose careers had developed at Care, transitions into management were seen as more natural or normalized, even for doctors like Robert. At Specialist, there was a sharper differentiation between clinicians and management, which led to a more conscious acceptance of the role by doctors such as Brenden, if not at first by nurses such as Nina. More generally, these differences in the perceived flexibility and permeability of 
occupational boundaries variously enabled or constrained individuals' hybrid management career aspirations and trajectories (cf. Inkson et al., 2012).

This leads to a further series of points about the effects of context that relate to the second research question. The accounts suggest there were important ways in which distinct organizational contexts shaped the opportunities and constraints afforded to hybrid managers. Despite having much in common in career development - particularly the importance attached to experience across divisional boundaries and in outreach activities - hybrid manager legitimacy and credibility was based upon different constellations of factors. Patient group features and external service building or internal service integration processes were important in shaping career orientations at Care; experience of multiple clinical domains and an orientation to service improvement and cross-disciplinary team-working were important at Acute; and specialist clinical knowledge and an orientation to medical science research and teaching activities were significant at Specialist. In all three cases, professional (clinical) experience was an essential element in the professional make-up of hybrid managers. However, expectations of continued professional practice and patterns of career progression varied depending upon their alignment with the type of health care delivered and local organizational strategies and circumstances.

Consequently, a range of organisational circumstances come into play in shaping the nature and response to clinical/managerial hybridity. These include: the nature, range and diversity of clinical specialisms and patient groups; the differentiation of services provision (geographical and organizational) and associated integration challenges; the susceptibility of the service to financial and other pressures associated with wider healthcare reforms; and organizational strategies adopted by the organizations concerned (of growth, diversification, cost reduction, 
modernization, etc). Such effects might be direct (as in the case of financial cuts); or indirect (through impact on organizational structural/cultural attributes). Crucially, though, they did not simply constrain hybrid management identity, they also provided opportunities for individuals themselves - particularly those with more power and influence - to shape their own approach to hybridity as it pertained to their particular context (cf. McDermott et al., 2013).

This is not meant to suggest a breakdown of traditional professional and managerial career paths, as it was clear from the ambivalence and agnosticism shown in many accounts that more bounded professional career paths still exerted a very strong influence (Inkson et al., 2012; Rodrigues and Guest, 2010). It was clear too that there were differential effects that, instead of obscuring or lessening existing status and power differentials (e.g. between doctors and nurses), tended to reflect and reinforce them. However, it does suggest the emergence of more flexible and permeable boundaries that provided opportunities for hybrid managers to develop their identity and careers in often quite distinct ways.

Whatever the precise implications for the development of professional management capabilities, the general observation is that variable conditions require a more nuanced interpretation of hybrid managerial identity - one sensitive to the interplay of managers' selfidentities and the influence of institutional and organizational conditions in which they are embedded (and which, in turn, feed into their interpretation of management activities and roles and their in situ development over time).

\section{Conclusion}


This paper has unpacked the concept of hybrid manager with reference to the healthcare sector. It has suggested a more variegated, contextualized and dynamic interpretation of what it means to become and be a hybrid manager, and demonstrated how a situated analysis is vital in understanding the nature, enactment and evolution of the role. It has particularly emphasized how managerial orientations vary widely amongst hybrid managers and how doctors and nurses may diverge, but also converge, in important respects with regard to clinical/managerial identities. Factors such as professional background and experience, as well as relative organizational position and longevity are therefore of importance.

What the effects of different organizational circumstances and experiences also suggest are that different types of healthcare organization - and their associated systems and cultures may enable or inhibit the development of diverse types of hybrid manager (cf. Dopson et al., 2008). Organizational and extra-organizational influences were clearly important in shaping managerial careers and orientations towards management. Such changes variously created or disrupted internal and external career development pathways and could thus constrain, enable or punctuate career choices and trajectories for particular individuals and groups (cf. Inkson et al., 2012).

The paper has, of course, drawn upon accounts of hybridity in only three healthcare settings. Although these were selected to provide variation in healthcare organization, more research is needed to ensure the full range of potential mediating influences across different types of setting has been captured. Research might also usefully chart more systematically the likely effects of these and other influences on shaping managers' emerging hybridity and professional identity and how these relate to established organizational typologies (e.g. Lam, 2000). However, in identifying and examining career trajectories in relation to various types of hybrid 
manager and in exploring those differences across diverse types of healthcare setting, an important start has been made here in showing how hybridity is more complex and dynamic than often portrayed (cf. Noordegraaf, 2015).

This has a number of important implications for understanding the trajectory of change in the management of healthcare organizations, particularly given the challenges facing healthcare management in the current context (Hyde et al., 2016). the spread of managerialism within the sector (Davies and Harrison, 2003) and growing expectations on (hybrid) managers to exercise more leadership in dealing with the pressures to improve efficiency and cost effectiveness as well as deliver more effective patient care (e.g. Bresnen et al., 2015). For example, one might expect hybridity to be not only a potential benefit for, but also a more significant challenge to the management of organizations such as traditional general hospitals. In other healthcare settings, the emergence/enactment of hybrid management roles may be no less a personal and professional challenge, but rather easier to align with organizational strategies, structures and cultures. By the same token, one might expect contemporary changes in healthcare to have important implications for the extent to which hybrid managers are able to meet the challenges which face them. In sum, whatever the precise scenario and effects of (and effects on) hybrid managers, it is clear that the concept of hybrid managerial identity needs to take greater account of its variegated, situational and dynamic qualities to present a more complete picture of what it means to become and to be a hybrid manager.

\section{Acknowledgements}

This research was funded by the UK's National Institute for Health Research Service Delivery and Organisation (NIHR SDO) programme (project number 09/1002/29). The views and 
opinions expressed therein are those of the authors and do not necessarily reflect those of the SDO programme, NIHR, NHS or the Department of Health.

\section{References}

Alvesson, M. (2010) Self doubters, strugglers, storytellers, surfers and others: images of selfidentities in organization studies. Human Relations, 63, 193-217.

Alvesson, M., Ashcraft, K. L. and Thomas, R. (2008) Identity matters: reflections on the construction of identity scholarship in organization studies. Organization, 15(1), 5-28.

Alvesson, M. and Willmott, H. (2002) Identity regulation as organizational control: producing the appropriate individual. Journal of Management Studies, 39(5), 619-644.

Ashforth, B. E. (2001) Role transitions in organizational life: an identity-based perspective. Mahwah, NJ: Lawrence Erlbaum Associates.

Bamber, M., Allen-Collinson, J. and McCormack, J. (2017). "Occupational limbo, transitional liminality and permanent liminality: New conceptual distinctions." Human Relations 70(12): 1514-1537.

Beech, N. (2011) Liminality and the practices of identity reconstruction. Human Relations, 64(2) 285-302.

Bolton, S. C. (2005) 'Making up' managers: the case of NHS nurses. Work, Employment and Society, 19(1), 5-23.

Bresnen, M., Hodgson, D., Bailey, S., Hyde, P. and Hassard, J. (2017) Mobilizing management knowledge in healthcare: institutional imperatives and professional and organizational mediating effects. Management Learning, 48(5), 597-614.

Brocklehurst, M., Grey, C. and Sturdy, A. (2010) Management: the work that dares not speak its name. Management Learning, 41(1), 7-19.

Brooks I. (1999) Managerialist professionalism: the destruction of a non-conforming subculture. British Journal of Management, 10(1):41-52.

Brown, A. (2015) Identities and identity work in organizations. International Journal of Management Reviews, 17, 20-40. 
Buchanan, D., Addicott, R., Fitzgerald, L., Ferlie, E. and Baeza, J. (2007) Nobody in charge: distributed change agency in healthcare. Human Relations, 60(7), 1065-1090.

Buchanan, D. (2013) Pure plays and hybrids: acute trust management profile and capacity. Journal of Health Services Research \& Policy, 18(2), 90-97.

Burgess, N. and G. Currie (2013) The knowledge brokering role of the hybrid middle level manager: the case of healthcare. British Journal of Management, 24, S132-S142.

Burgess, N., K. Strauss, G. Currie and G. Wood (2015) Organizational ambidexterity and the hybrid middle manager: the case of patient safety in UK hospitals. Human Resource Management, 54(S1), S87-S109.

Collinson, D. (2003) Identities and insecurities: selves at work. Organization, 10(3): 527-47.

Croft, C., Currie, G. and Lockett, A. (2014) Broken 'two-way windows'? An exploration of professional hybrids. Public Administration.

Croft, C., Currie, G. and Lockett, A. (2015) The Impact of emotionally important social identities on the construction of a managerial leader identity: a challenge for nurses in the English National Health Service. Organization Studies, 36(1), 113-131.

Currie, G. (1997) Contested Terrain: The incomplete closure of managerialism in the health service. Health Manpower Management 23(4): 123-132.

Currie, G. (2006) Reluctant but resourceful middle managers: the case of nurses in the NHS Journal of Nursing Management, 14, 5-12.

Currie, G. and Croft, C. (2015) Examining hybrid nurse managers as a case of identity transition in healthcare: developing a research agenda. Work, Employment and Society, 29(5), 855-65.

Currie, G., Finn, R., \& Martin, G. (2009). Professional Competition and Modernizing the Clinical Workforce in the NHS. Work, Employment and Society, 23(2), 267-284.

Currie, G., R. Finn and G. Martin (2010) Role transition and the interaction of relational and social identity: new nursing roles in the English NHS. Organization Studies, 31(7), 941-961.

Currie, G. and L. White (2012) Inter-professional barriers and knowledge brokering in an organizational context: the case of healthcare. Organization Studies, 33(10), 1333-1361.

Czarniawska-Joerges, B. (1994) Narratives of individual and organizational identities. In S. Deetz (ed.) Communication yearbook. Newbury Park, CA: Sage. 193-221. 
Davies, H. T. O. and Harrison, S. (2003) Trends in doctor-manager relationships. $B M J$, 326(March), 646-9.

Dellve, L. and Wikström, E. (2009) Managing complex workplace stress in health care organizations: leaders' perceived legitimacy conflicts. Journal of Nursing Management, 17(8), 931-941.

Dopson, S. and Fitzgerald, L. (2006) The role of the middle manager in the implementation of evidence-based health care. Journal of Nursing Management, 14, 43-51.

Dopson, S. (1995). Management: The one disease consultants did not think existed. Journal of Management in Medicine, 8(5), 25-36.

Dopson, S., \& Fitzgerald, L. (Eds) (2005). Knowledge to action? Evidence-based health care in context. Oxford, Oxford University Press.

Dopson, S., L. Fitzgerald and E. Ferlie (2008) Understanding change and innovation in healthcare settings: reconceptualizing the active role of context. Journal of Change Management, 8(3-4), 213-31.

Ferlie, E., Fitzgerald, L., McGivern, G., Dopson, S. and Bennett, C. (2013) Making wicked problems governable? The case of managed networks in healthcare. Oxford: Oxford University Press.

Fitzgerald, L. \& Dufour, Y. (1997). Clinical management as boundary management: A comparative analysis of Canadian and UK healthcare institutions. International Journal of Public Sector Management, 10(1/2), 5-20.

Fitzgerald, L. \& Ferlie, E. (2000). Professionals: Back to the Future? Human Relations, 53(5), 713-739.

Hassard, J., McCann, L. and Morris, J. (2009) Managing in the modern corporation: the intensification of managerial work in the USA, UK and Japan. Cambridge: Cambridge University Press.

Hyde, P., E. Granter, J. Hassard and L. McCann (2016) Deconstructing the welfare state: Managing healthcare in the age of reform. London: Routledge

Ibarra, H. (1999) Provisional selves: experimenting with image and identity in professional adaptation. Administrative Science Quarterly, 44:764-91.

Ibarra, H. and Barbulescu, R. (2010) Identity as narrative: prevalence, effectiveness, and consequences of narrative identity work in macro work role transitions. Academy of Management Review, 35(1), 135-154. 
Iedema, R., Degeling, P., Braithwaite, J. and White, L. (2004) "It's an interesting conversation I'm hearing": the doctor as manager. Organization Studies, 25(1): 15-33.

Inkson, K., Gunz, H., Ganesh, S. and Roper, J. (2012) Boundaryless careers: bringing back boundaries. Organization Studies, 33(3), 323-340.

Kippist, L. and Fitzgerald, A. (2009) Organizational professional conflict and hybrid clinician managers. Journal of Health Organization and Management, 23(6), 642-655.

Kislov, R. (2014) Boundary Discontinuity in a Constellation of Interconnected Practices. Public Administration, 92(2), 307-23.

Kitchener, M. (2000). The "Bureaucratization' of Professional Roles: The case of clinical directors in UK hospitals. Organization, 7(1), 129-154.

Knights, D., \& McCabe, D. (2003). Governing through teamwork: reconstituting subjectivity in a call centre. Journal of Management Studies, 40(7), 1587-1619.

Kreiner, G. E., Hollensbe, E. C. and Sheep, M. L. (2006) Where is the 'me' among the 'we'? Identity work and the search for optimal balance. Academy of Management Journal, 49(5), 1031-1057.

Lam, A. (2000) Tacit knowledge, organizational learning and societal institutions: an integrated framework. Organization Studies, 21(3), 487-513.

Learmonth, M. and Humphreys, M. (2012) Autoethnography and academic identity: glimpsing business school doppelgangers. Organization, 19(1), 99-117.

Llewellyn, S. (2001) 'Two-way windows': clinicians as medical managers. Organization Studies, 22(4), 593-623.

McConville T. (2006) Devolved HRM responsibilities, middle-managers and role dissonance. Personnel Review, 35(6), 637-53.

McDermott, A., Fitzgerald, L. and Buchanan, D. (2013) Beyond acceptance and resistance: entrepreneurial change agency responses in policy implementation. British Journal of Management, 24, S93-115.

McGivern, G., G. Currie, E. Ferlie, L. Fitzgerald and J. Waring (2015) Hybrid managerprofessionals' identity work: the maintenance and hybridization of professionalism in managerial contexts. Public Administration, 93, 2, 412-432. 
McMurray, R. (2010) The struggle to professionalize: an ethnographic account of the occupational position of Advanced Nurse Practitioners. Human Relations, 64(6), 801-822.

Noordegraaf, M. (2015) Hybrid professionalism and beyond: (new) forms of public professionalism in changing organizational and societal contexts. Journal of Professions and Organization, 2015.

Paton, S. and Hodgson, D. (2016) Project managers on the edge: liminality and identity in the management of technical work. New Technology, Work and Employment, 31(1), 26-40.

Reay, T., Goodrick, E., Waldorff, S. B., \& Casebeer, A. (2017). Getting leopards to change their spots: Co-creating a new professional role identity. Academy of Management Journal, 60(3), 1043-1070.

Rodrigues, R. A. and Guest, D. (2010) Have careers become boundaryless? Human Relations, 63(8), 1157-1175.

Spyridonidis, D., Hendy, J. and Barlow, J. (2015) Understanding hybrid roles: the role of identity processes amongst physicians. Public Administration, 93(2), 395-411.

Sveningsson, S. and Alvesson, M. (2003) Managing managerial identities: organizational fragmentation, discourse and identity struggle. Human Relations, 56(10), 1163-1193.

Tansley, C. and Tietze, S. (2013) Rites of passage through talent management progression stages: an identity work perspective. International Journal of Human Resource Management, 24 (9), 1799-1815.

Thomas, R. and Linstead, A. (2002) Losing the plot? Middle managers and identity. Organization, 9(10), 71-93.

Thorne, M. (1997). Being a clinical director: First among equals or just a go between? Health Services Management Journal, 10, 205-215.

von Knorring M, Alexanderson K, Eliasson, A. (2016) Healthcare managers' construction of the manager role in relation to the medical profession. Journal of Health Organization and Management, 39(3), 421-440.

Waring, J. (2007) Adaptive regulation or governmentality: patient safety and the changing regulation of medicine. Sociology of Health \& Illness, 29(2), 163-179.

Watson, T. J. (1994) In search of management. London: Routledge.

Watson, T. J. (2008) Managing identity: identity work, personal predicaments and structural circumstances. Organization, 15(1), 121-143. 
Watson, T. J. (2009) Narrative life story and manager identity: a case study in autobiographical identity work. Human Relations, 62(3), 425-452.

Weick, K. E. (1995) Sensemaking in organizations. Thousand Oaks, CA: Sage. 
Figure 1: Manager selection framework

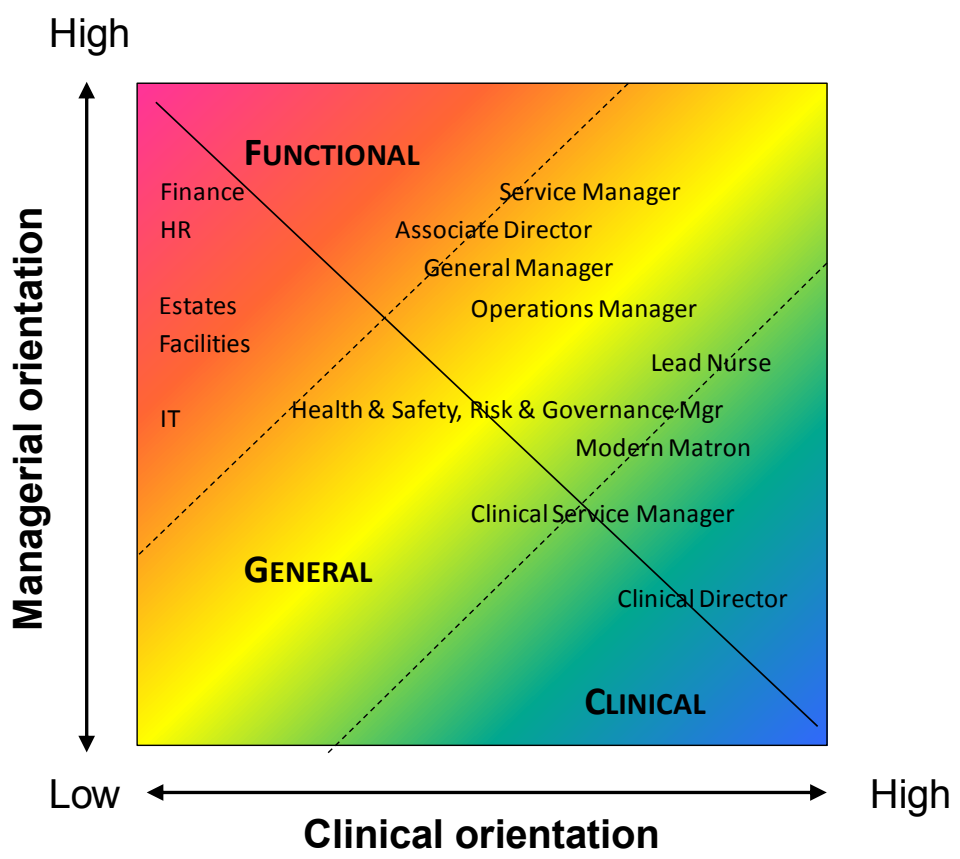


Table 1: Interviewees by management group and by trust

\begin{tabular}{|l|l|l|l|l|l|} 
& $\begin{array}{l}\text { Clinical } \\
\text { managers }\end{array}$ & $\begin{array}{l}\text { General } \\
\text { managers }\end{array}$ & $\begin{array}{l}\text { Functional } \\
\text { managers }\end{array}$ & $\begin{array}{l}\text { Total } \\
\text { participants }\end{array}$ & $\begin{array}{l}\text { Total } \\
\text { interviews }\end{array}$ \\
\hline Acute Trust & 5 & 8 & 7 & 20 & 22 \\
\hline Care Trust & 7 & 12 & 6 & 25 & 33 \\
\hline Specialist Trust & 6 & 9 & 8 & 23 & 30 \\
\hline Total & 18 & 21 & 29 & 68 & 85 \\
\hline
\end{tabular}


Table 2: Clinical backgrounds and qualifications

\begin{tabular}{|c|c|c|c|c|c|}
\hline Trust & Cohort & $\begin{array}{l}\text { Numbers with } \\
\text { clinical } \\
\text { backgrounds }\end{array}$ & $\begin{array}{l}\text { Clinical } \\
\text { qualifications or } \\
\text { PhD }\end{array}$ & $\begin{array}{l}\text { BSc/Dip/MSc } \\
\text { healtheare } \\
\text { qualifications }\end{array}$ & $\begin{array}{l}\text { Total } \\
\text { in } \\
\text { cohort }\end{array}$ \\
\hline \multirow{6}{*}{ Acute } & \multirow{3}{*}{ Clinical } & 2 Doctors & $2 \mathrm{MD}$ & \} & \multirow[t]{3}{*}{5} \\
\hline & & 2 Nurses & $2 \mathrm{RGN}^{1}$ & 2 & \\
\hline & & 1 Scientist & $1 \mathrm{PhD}$ & \} & \\
\hline & \multirow[t]{2}{*}{ General } & 1 Nurse & $1 \mathrm{SRN}^{2}$ & \} 10 & \multirow[t]{2}{*}{8} \\
\hline & & 4 AHPs & - & \} & \\
\hline & Functional & 1 Nurse & $1 \mathrm{RGN}$ & 1 & 7 \\
\hline \multirow[t]{6}{*}{ Care } & \multirow[t]{3}{*}{ Clinical } & 2 Doctors & $2 \mathrm{MD}$ & \} & \multirow[t]{3}{*}{7} \\
\hline & & 3 Nurses & $2 \mathrm{RGN}+1 \mathrm{RMN}^{3}$ & \} 10 & \\
\hline & & 2 AHPs & - & \} & \\
\hline & \multirow[t]{2}{*}{ General } & 10 Nurses & $7 \mathrm{RMN}+3 \mathrm{RGN}$ & \} 9 & \multirow[t]{2}{*}{12} \\
\hline & & 2 Social workers & - & \} & \\
\hline & Functional & - & - & 1 & 6 \\
\hline \multirow[t]{7}{*}{ Specialist } & \multirow[t]{4}{*}{ Clinical } & 1 Doctor & $1 \mathrm{MD}$ & \} & \multirow[t]{4}{*}{6} \\
\hline & & 3 Nurses & $3 \mathrm{RGN}$ & 5 & \\
\hline & & $1 \mathrm{AHP}$ & - & \} & \\
\hline & & 1 Scientist & $1 \mathrm{PhD}$ & \} & \\
\hline & \multirow[t]{2}{*}{ General } & 3 Nurses & $1 \mathrm{BSc}+2 \mathrm{RGN}$ & \} 3 & \multirow[t]{2}{*}{9} \\
\hline & & 2 Scientists & - & \} & \\
\hline & Functional & 1 Scientist & $1 \mathrm{PhD}$ & 3 & 8 \\
\hline Total & & 42 & 31 & 44 & 68 \\
\hline
\end{tabular}

${ }^{1}$ Registered General Nurse; ${ }^{2}$ State Registered Nurse; ${ }^{3}$ Registered Mental Nurse 
Table 3: Career narratives: Hybrid manager types and exemplars by trust

\begin{tabular}{|c|c|c|c|c|}
\hline 'Type' & Narrative & Acute trust exemplar & Care trust exemplar & Specialist trust exemplar \\
\hline Aspirational & $\begin{array}{l}\text { Nurses } \\
\text { ambitious to } \\
\text { progress into } \\
\text { management } \\
\text { and keen to } \\
\text { make a } \\
\text { difference }\end{array}$ & $\begin{array}{l}\text { Melissa, Associate Director: } \\
\text { I quickly recognized that I wanted to work at a } \\
\text { more senior grade ... I was in an acute ward, } \\
\text { looking after stroke patients. I had a team ... and } \\
\text { the team worked well ... I started to think: do you } \\
\text { know, this is great ... but if I want to do this on a } \\
\text { bigger scale then I'm going to have to think } \\
\text { differently. That's when the seed was planted. }\end{array}$ & $\begin{array}{l}\text { Hasin, Operations Manager: } \\
\text { The seed around management ... was planted } \\
\text { when I was still working ... as a [senior] staff } \\
\text { nurse ... When I went into acute services, one of } \\
\text { my colleagues ... [said] "you seem to have the } \\
\text { right aptitude to be in management". It was just } \\
\text { an observation. But ... it was a seed that was } \\
\text { planted. }\end{array}$ & $\begin{array}{l}\text { Becky, Service Manager: } \\
\text { I did two years on the wards and worked in } \\
\text { chemotherapy, radiotherapy and combined } \\
\text { services... I'd had a lot of work experience so I } \\
\text { didn't want to just work for x number of years and } \\
\text { become a ward sister and ... ward manager. I } \\
\text { wanted a management pathway ... I have always } \\
\text { wanted to be in a leadership role. }\end{array}$ \\
\hline \multirow[t]{2}{*}{ Ambivalent } & $\begin{array}{l}\text { Nurses } \\
\text { comfortable } \\
\text { with and/or } \\
\text { adaptable to } \\
\text { management }\end{array}$ & $\begin{array}{l}\text { Roxanne, Programme Manager: } \\
\text { Went into nursing. Loved it ... I just wanted to get } \\
\text { more into managing, a senior clinical role ... I was } \\
\text { being encouraged to go into director's roles ... But } \\
\text { decided that I like the detail. I didn't want that high } \\
\text { level overarching role ... I liked getting involved } \\
\text { with ... improving patient care. So it really } \\
\text { challenged me about where I wanted to go next in } \\
\text { my career. }\end{array}$ & $\begin{array}{l}\text { Harriet, Operations Manager: } \\
\text { I moved into a senior management role and it was } \\
\text { by accident because I was managing the } \\
\text { children's and adult's and forensic team and we } \\
\text { had two failing ... residential services, both } \\
\text { subject to external reviews ... It was a case of: } \\
\text { this service is failing we need to put a turnaround } \\
\text { team in, will you head that up? So that's what } \\
\text { we did. }\end{array}$ & $\begin{array}{l}\text { Hannah, Service Manager: } \\
\text { I've never had a clear view of where I wanted to } \\
\text { end up really. I've taken opportunities when I've } \\
\text { wanted to take them if the opportunities arise and } \\
\text { I felt interested in ... I take the stance: if } \\
\text { somebody else did it, do you feel you could do } \\
\text { the same or a better job? ... Things have just } \\
\text { evolved really as I've gone along. }\end{array}$ \\
\hline & $\begin{array}{l}\text { Doctors } \\
\text { persuaded } \\
\text { into, and not } \\
\text { averse to, } \\
\text { management }\end{array}$ & $\begin{array}{l}\text { Ramesh, Clinical Director: } \\
\text { I was not willing to relinquish my clinical } \\
\text { commitments until I was completely sure ... So I } \\
\text { took it as an additional responsibility that was an } \\
\text { added pressure. Having said that, I realised you're } \\
\text { able to do more when there is pressure. You } \\
\text { function better. You are more planned, more } \\
\text { organised because time [is] precious. }\end{array}$ & $\begin{array}{l}\text { Robert, Clinical Director: } \\
\text { As lead consultant ... [I] have to maintain two } \\
\text { very opposing forces ... On one hand, I've got } \\
\text { the Trust saying this needs to be done, we need } \\
\text { to trim down on that level of input. On the other } \\
\text { side, I've got the patient side and the carers ... } \\
\text { [wanting] the best patient care. You do find } \\
\text { yourself in the middle being pulled both ways. }\end{array}$ & $\begin{array}{l}\text { Brenden, Divisional Director: } \\
\text { What can happen in medicine and ... it happened } \\
\text { in my area is, you specialise in your clinical } \\
\text { subject, you get your consultant job and your } \\
\text { head is immersed in that ... Then suddenly the } \\
\text { Trust knocks on your door and says do you mind, } \\
\text { can you spare a few minutes? And you find } \\
\text { yourself [experiencing] an abrupt change. }\end{array}$ \\
\hline Agnostic & $\begin{array}{l}\text { Doctors / } \\
\text { nurses more } \\
\text { sceptical } \\
\text { about } \\
\text { management } \\
\text { or deterred } \\
\text { from it }\end{array}$ & $\begin{array}{l}\text { Oliver, Chief Pharmacist: } \\
\text { Being a general manager is not a career I want to } \\
\text { pursue. I've worn the T-shirt and I can look anyone } \\
\text { in the face who's done medicine and sympathize } \\
\text { with them. But to me pushing beds round or asking } \\
\text { people to see patients to stop a breach really isn't } \\
\text { my thing. }\end{array}$ & $\begin{array}{l}\text { Justine, Service Manager: } \\
\text { I became a service manager ... and I was still } \\
\text { carrying a caseload of } 100 . \text { I did that for about a } \\
\text { year and I found that I couldn't do it. I was quite } \\
\text { ill, depression, handed my notice in, didn't have } \\
\text { anywhere to go ... and then they asked me to stay } \\
\text { on in a consultative role when I returned from } \\
\text { sick. }\end{array}$ & $\begin{array}{l}\text { Beryl, Divisional Lead Nurse: } \\
\text { I went for Nurse Consultant [because] I wasn't } \\
\text { sure which way my career wanted to go. I looked } \\
\text { at management, I wasn't sure. Looked at } \\
\text { research, wasn't sure. Looked at education ... } \\
\text { [but] ... education full-time wasn't the right } \\
\text { thing. I applied for a research bursary ... But, } \\
\text { again, pure research wasn't me either. }\end{array}$ \\
\hline
\end{tabular}


Table 4: Career narratives: Aspirational hybrid managers

\begin{tabular}{|c|c|c|}
\hline Acute trust exemplar & Care trust exemplar & Specialist trust exemplar \\
\hline Melissa, Associate Director: & \multirow{6}{*}{$\begin{array}{l}\text { Hasin, Operations Manager } \\
\text { There were a number of opportunities coming up around } \\
\text { A\&E services. Mental health establishments were asked } \\
\text { to develop A\&E services ... and an opportunity came up } \\
\text { to apply for ... a G grade role ... to develop that service } \\
\ldots . \text { It was very much a clinical role with some managerial } \\
\text { role ... The managerial element was very much around ... } \\
\text { setting up care pathways, agreeing the service model and } \\
\text { providing supervision. } \\
\text { In 2004, there was a real crisis for our drug and alcohol } \\
\text { services ... I was approached by one of the senior } \\
\text { managers and asked if I would go and provide cover .... } \\
\text { The only grade that they had was an I grade ... [and so] I } \\
\text { joined them as an acting senior service manager }\end{array}$} & Becky, Service Manager: \\
\hline $\begin{array}{l}\text { An opportunity arose for me to become a team leader for } \\
\text { [an elderly person's integrated care service] ... I had a } \\
\text { bigger team; it wasn't just physios, it was a multi- } \\
\text { professional team, and there was psychology and various } \\
\text { different disciplines involved. [I] started to manage the } \\
\text { team, but also had [a] clinical caseload. }\end{array}$ & & $\begin{array}{l}\text { I wanted to work somewhere where there was excellent } \\
\text { cancer care. But I also wanted to understand why people } \\
\text { get cancer. That's why I went into research. Then ... I } \\
\text { started to see that the hospital had failings in areas around } \\
\text { patient experience and wanted to make some } \\
\text { improvements in the pathways for patients. }\end{array}$ \\
\hline $\begin{array}{l}\text { The therapy manager job came up ... and I was successful } \\
\text { in getting that position. And I loved it, because being able }\end{array}$ & & $\begin{array}{l}\text { I wanted to branch out into some form of management and } \\
\text { there were quite a few opportunities in [cancer] trials ... }\end{array}$ \\
\hline & & $\begin{array}{l}\text { An opportunity came up [for] secondment for a year, } \\
\text { looking at [improving] patient experience and patient }\end{array}$ \\
\hline So he created a new structure and he said, "I want you as & & pathways ... Service management was something I ... \\
\hline $\begin{array}{l}\text { my deputy, and I want you to manage the laboratory as well } \\
\text { [and] keep therapies." ... So that's what I did and I was the } \\
\text { Deputy Divisional Manager. }\end{array}$ & & $\begin{array}{l}\text { hadn't done before. But the senior management team here } \\
\text { thought: you've led on these projects, you've done all this } \\
\text { operational change, you know a lot of people ... That's } \\
\text { how I got into this service management position. }\end{array}$ \\
\hline
\end{tabular}




\begin{tabular}{|c|c|c|}
\hline Acute trust exemplar & Care trust exemplar & Specialist trust exemplar \\
\hline Roxanne, Programme Manager: & Harriet, Operations Manager: & Hannah, Service Manager: \\
\hline $\begin{array}{l}\text { When I went into midwifery, I wanted to develop a longer } \\
\text { term relationship with clients ... and that took me into } \\
\text { health visiting ... which in turn fed into preventative work } \\
\text { [and] public health ... From that, I got approached to go } \\
\text { into management ... [in] primary care development. } \\
\text { I was approached ... to see if I wanted to take on a } \\
\text { modernization role ... to set up integrated care pathways } \\
\text { and services out in the community. I took on that role ... } \\
\text { and I set up a lot of services in the area and worked with } \\
\text { clinicians ... and community specialist nurses ... It really } \\
\text { was bridging across the services. So that was quite a big } \\
\text { role, spanned a range of work. I managed quite a big team } \\
\ldots \text { [I] really got involved in the modernisation programme } \\
\ldots \text { and because of my nursing, clinical background it felt } \\
\text { like a really natural move, that it bridged that knowledge of } \\
\text { clinical processes plus developing better management } \\
\text { processes and ways of delivering critical care. }\end{array}$ & $\begin{array}{l}\text { I did my training in a year post-qualifying and then moved } \\
\text { into community services ... I moved around consciously } \\
\text { and with an intent on getting wide experience of } \\
\text { children's, adult's, residential, community. Then took on } \\
\text { a team leader role which was still very much a clinical role } \\
\ldots \text { There was some leadership and management } \\
\text { responsibilities, but not very much. } \\
\text { I decided I wanted to be a nurse consultant so I went away } \\
\text { and did a master's in clinical work, came back [to help] } \\
\text { put some bids together for nurse consultant posts ... [But] } \\
\text { the [authority] wouldn't approve them ... In the } \\
\text { meantime, I was asked to ... combine the services and ... } \\
\text { head that up for a short period of time until they reapplied } \\
\text { for the [posts]. But that didn't happen. And I just went } \\
\text { from the team manager of that service into generally } \\
\text { managing the adult LD teams and then into a senior } \\
\text { manager role. So it was accidental I guess. }\end{array}$ & $\begin{array}{l}\text { I worked my way up to ward manager. And then a post } \\
\text { came available for a matron for three wards [including } \\
\text { mine] ... The Ward Manager's post is still quite clinical } \\
\text { so you spend part of your time managing the unit and the } \\
\text { staff within it and also part of your time clinically working } \\
\text { there. The Matron's post was less so but still had a clinical } \\
\text { part in it, so I still worked on some of the units ... The } \\
\text { Service Manager post sort of evolved after that ... } \\
\text { Chemotherapy had grown massively over the past five } \\
\text { years and they realized they needed a service lead for that } \\
\text { - not just the delivery of the treatment, more to do with } \\
\text { the activity role and the service side of it ... Just managing } \\
\text { that and moving it forward very quickly meant that I spent } \\
\text { a lot of time with chemotherapy ... So my clinical work } \\
\text { has got less and an awful lot smaller and it's more } \\
\text { management ... I still work clinically on the unit } \\
\text { occasionally but that's more to do with staffing issues. }\end{array}$ \\
\hline
\end{tabular}




\begin{tabular}{|c|c|c|}
\hline Acute trust exemplar & Care trust exemplar & Specialist trust exemplar \\
\hline Ramesh, Clinical Director: & Robert, Clinical Director: & Brenden, Divisional Director: \\
\hline $\begin{array}{l}\text { One thing I've learned looking at some senior leaders is } \\
\text { your feet have to be on the ground because you've got to } \\
\text { come back to the fact that you're a clinician. }\end{array}$ & $\begin{array}{l}\text { I'm obviously a trained doctor. But, in the position I'm in } \\
\ldots \text { I've seen how that interacts with the wider world ... So } \\
\text { I still have to recognise constraints. }\end{array}$ & $\begin{array}{l}\text { Did I have the expertise in the managerial side? I would say } \\
\text { probably not, except what rubs off just during your career. } \\
\text { You find yourself ... at the top table with ... other directors, }\end{array}$ \\
\hline $\begin{array}{l}\text { I did take it on with a very clear statement to the divisional } \\
\text { director: I will take it on for four months as a pilot ... The } \\
\text { two key things were whether I feel I'm able to deliver what } \\
\text { is required, and the second is judgement on what impact it's } \\
\text { having on the family. }\end{array}$ & $\begin{array}{l}\text { Over the last couple of years, it's been a lot about } \\
\text { efficiency and cost saving. You know, how we're going } \\
\text { to manage the problems in doctor recruitment that we're } \\
\text { all facing ... So it's about how we get our current teams } \\
\text { to take on more work ... There's a lot more around }\end{array}$ & $\begin{array}{l}\text { looking at the bigger picture of how this Trust is being run } \\
\ldots \text { I found that a little bit difficult ... I'm very interested to } \\
\text { put my bit in, but ... to be constructive, you need a little bit } \\
\text { more background reading and a little bit more getting your } \\
\text { head around things. You've got your clinical work which ... }\end{array}$ \\
\hline $\begin{array}{l}\text { Because I'm a geriatrician and a stroke [specialist], they're } \\
\text { predominantly ward based activities ... [others] might have } \\
\text { a lot of out-patient activity and procedural elements which } \\
\text { are a bit more difficult. Whereas the ward based activity [is] } \\
\text { more flexible ... So that was fortunate just by the speciality } \\
\text { I'm in ... I was [also] fortunate to come to a department } \\
\text { where there [were] very clear values and principals and } \\
\text { disciplines set already ... All I did is follow the same but } \\
\text { allowed a bit more [flexibility]. }\end{array}$ & $\begin{array}{l}\text { governance implementation of national agendas. We're } \\
\text { the go between, if you like, between them and the clinical } \\
\text { work. } \\
\text { We're an income generating directorate. So I see that as } \\
\text { a very positive thing because ... the Trust lets me get on } \\
\text { with my role. As long as they see that we're ... continuing } \\
\text { to support other services, they're quite happy for me to go } \\
\text { about it my way - which is really good, it's a positive } \\
\text { thing. }\end{array}$ & $\begin{array}{l}\text { you can't rein in. That is always a pressure ... You are } \\
\text { finding yourself at the management board of the hospital } \\
\text { talking about ... big decisions in terms of delivery of care } \\
\text { and I find that a little bit difficult ... [While] I have an } \\
\text { opinion as an experienced consultant ... there is a huge } \\
\text { depth of knowledge in this particular subject which, by } \\
\text { virtue of time and everything else, I haven't taken the time } \\
\text { to read through. }\end{array}$ \\
\hline
\end{tabular}

